\title{
Modal Kerja Dan Laba Ditahan Merupakan Prediktor Yang Positif Terhadap Laba Perusahaan
}

\author{
Chynviony Hadi dan Andi Wijaya \\ Program Studi Manajemen Fakultas Ekonomi Universitas Tarumangara, Jakarta \\ Email : chynviony.115150288@stu.untar.ac.id
}

\begin{abstract}
Abstrak: Penelitian ini bertujuan untuk menguji secara empiris modal kerja dan laba ditahan merupakan prediktor yang positif terhadap laba perusahaan pada PT. Nippon Indosari Corpindo Tbk. Hal ini dilakukan dengan analisis hubungan variabel independen (modal kerja dan laba ditahan) terhadap variabel dependen (laba kotor perusahaan) secara bersama - sama dan parsial dengan metode riset deskriptif kuantitatif, yaitu analisis data sekunder laporan keuangan digunakan untuk meramalkan keadaan dimasa yang akan datang dengan memperhatikan kecenderungan - kecenderungan yang terjadi serta studi korelasi untuk menetapkan besaran hubungan antar variabel yang diteliti. Dimana sebelumnya telah lolos uji dari keempat asumsi klasik. Hasil uji empiris bersama - sama mempunyai korelasi yang positif serta signifikan antara kedua variabel independen dengan variabel dependen dan ujian parsial laba ditahan juga berkorelasi positif dan signifikan dengan laba kotor perusahaan, tetapi modal kerja berkorelasi negatif dan lemah signifikansinya dengan laba kotor perusahaan. Hal ini mungkin disebabkan adanya kenaikan yang sangat tinggi modal kerja pada tahun 2017.
\end{abstract}

Keywords: Prediksi Laba Kotor, Laba, Modal Kerja, Laba Ditahan.

Abstract: The purpose of this research is to empirically examine working capital and retained earning as positive predictors of corporate profit at PT. Nippon Indosari Corpindo Tbk. This is done by analyzing the correlation of independent variable (working capital and retained earning) to dependent variable (corporate gross profit) simultaneously and partially with quantitative descriptive research methods, is secondary data, financial statement analysis that are used to predict future conditions by taking into account trends that occur and study correlations to determine the magnitude of the relationships between variables examined. Which previously passed the test of four classic assumptions. The results of simultaneous empirical tests have a positive and significant correlation between the two independent variables with the dependent variable and partial test of retained earnings also positively and significantly correlated with the company's gross profit, but working capital is negatively correlated and weakly significant with the company's gross profit. This might be due to a very high increase in working capital in 2017. 


\section{LATAR BELAKANG}

Modal kerja adalah total aset lancar yang digunakan untuk membiayai semua kegiatan operasi perusahaan sehari - hari guna menghasilkan produk dan kemudian akan masuk kembali kedalam perusahaan melalui proses dari hasil penjualan barang produksi dalam jangka waktu pendek dan berputar terus sampai suatu akhir periode akan dihitung seberapa besar keuntungan yang didapat, sesudah dikurangi harga pokok produksi yang biasanya disebut laba kotor. Laba kotor ini untuk membiayai semua beban usaha termasuk biaya bunga serta pajak dan sisanya sebagai laba bersih. Modal kerja ini akan berputar terus sepanjang umur perusahaan. Sedangkan laba ditahan adalah laba bersih dikurangi deviden yang dibayarkan kepada pemegang saham. Laba yang ditahan ini akan diakumulasi dan dilaporkan pada ekuitas perusahaan dalam laporan perubahan modal dan merupakan salah satu sumber pendanaan atau pembiayaan internal serta dapat digunakan untuk reinvestasi dalam pengembangan perusahaan dan untuk melunasi beban hutang, sehingga laba ditahan sangat diperlukan perusahaan sebagai sumber pembiayaan dan pendanaan investasi interen perusahaan.

Sementara peluang pasar yang paling menarik dan mudah diamati adalah peluang pasar konsumsi khususnya produk makanan dan minuman, hal ini disebabkan karena permintaan yang selalu meningkat sejalan dengan pertumbuhan penduduk yang selalu positif, dengan mobilitas penduduk semakin tinggi didukung pembangunan jalan dan jalan tol semakin panjang, semua daerah hampir bisa diakses alat transportasi dan sektor industri makanan dan minuman telah menjadi andalan penopang pertumbuhan manufaktur dan ekonomi nasional.

Penulis memilih perusahaan makanan dan minuman karena sektor usahanya memiliki peluang untuk tumbuh sangat bagus. Dalam penulisan ini, membatasi penelitian pada PT. Nippon Indosari Corporindo Tbk. dengan kode saham ROTI go public tanggal 23 Juni 2010 yang dipilih dengan acak, dengan judul "Modal Kerja dan Laba Ditahan Merupakan Prediktor yang Positif Terhadap Laba Perusahaan pada PT. Nippon Indosari Corpindo Tbk. Indonesia Periode 2010 sampai dengan tahun 2017”.

Modal kerja sangat penting dalam pembiayaan kegiatan operasi perusahaan bersifat jangka pendek, sehingga menjadi pertanyaan adalah seberapa signifikan variabel modal kerja dan laba ditahan menjadi prediktor yang positif terhadap laba kotor perusahaan. Penelitian sebelum juga telah banyak dilakukan untuk memprediksi profit pada masa akan datang. Hasil penelitian sebelum menunjukkan bahwa modal kerja kotor mempunyai hubungan yang positif dengan profit selama dalam batas-batas tertentu, dari jurnal-jurnal yang terdapat pada kajian teori diantaranya: Pertama Working capital financing and corporate profitability of Indian manufacturing firms. Menurut hasil penelitian ini terdapat hubungan cembung (positif) antara modal kerja dan laba perusahaan di industri makanan dan minuman, kimia dan konstruksi. Kedua Working capital level influence on SME profitability. Hasil empiris menunjukkan bahwa ada hubungan cekung (negatif) antara modal kerja dengan laba perusahaan. Ketiga Working capital management and firms' profitability: evidence from emerging Asian countries. Penelitian ini menunjukkan hubungan yang tidak linear antara laba perusahaan dengan manajemen modal kerja untuk sebelas sektor ekonomi di Asia Pasifik. Keempat The status of working capital and its relationship with sales. Hasil penelitian ini menunjukkan ketika penjualan naik secara positif, kuat dan signifikan berkaitan dengan kenaikan modal kerja baik di dunia usaha maupun industri. Maka dapat disimpulkan bahwa dari penelitian sebelum menunjukkan 
terdapat hubungan yang cembung maupun cekung antara tingkatan modal kerja dengan laba perusahaan. Artinya terdapat tingkat modal kerja optimal yang dapat menghasilkan laba maksimal, penambahan atau pengurangan modal kerja yang melewati batas tertentu akan dapat mengurangi laba perusahaan.

Retained earnings, dari hasil penelitian sebelumnya juga menunjukkan laba ditahan mempunyai hubungan yang positif dengan profit, jurnal-jurnal sebelumnya: pertama The implications of retained and distributed earnings for future profitability and stock returns. Hasil penelitian ini menunjukkan adanya perbedaan tingkat keyakinan antara laba ditahan dan laba dibagikan untuk laba perusahaan dan tingkat keuntungan yang didapat para pemegang saham di masa depan, dimana tingkat keyakinan lebih tinggi untuk laba ditahan daripada laba dibagikan. Kedua "Pengaruh Rasio Utang, Laba Ditahan, Return On Equity (ROE), dan Inflasi Terhadap Earnings Per Share (EPS) Perusahaan Makanan dan Minuman yang Terdaftar di Bursa Efek Indonesia (BEI) periode tahun 2008-2010”. Hasilnya menunjukkan laba ditahan berpengaruh positif terhadap Earnings Per Share (EPS) perusahaan makanan dan minuman.

Berdasarkan penelitian ini bahwa modal kerja dan laba ditahan merupakan prediktor positif terhadap laba kotor perusahaan secara bersama - sama; sedangkan secara parsial modal kerja mempunyai hubungan yang negatif terhadap laba kotor artinya penambahan modal kerja diatas optimal akan mengakibatkan laba kotor menurun dan sebaliknya (the law of diminishing return). Laba ditahan mempunyai hubungan yang positif terhadap laba kotor artinya semakin besar laba ditahan semakin besar laba kotor yang dihasilkan.

Berdasarkan penelitian ini maupun penelitian sebelumnya dapat disimpulkan bahwa modal kerja kotor yang optimal akan menghasilkan laba yang maksimal, sementara laba ditahan semakin besar akan menghasilkan laba kotor semakin besar. Demikian hasilnya sesuai dengan teori modal kerja yang efisien akan menghasilkan laba yang optimal (Riyanto: 2001).

Tujuan penelitian ini adalah: untuk menguji secara empiris besaran modal kerja dan besaran laba ditahan secara bersama - sama merupakan prediktor yang positif atas laba kotor perusahaan, untuk menguji secara empiris besaran modal kerja merupakan prediktor yang positif atas laba kotor perusahaan, dan untuk menguji secara empiris besaran laba ditahan merupakan prediktor yang positif atas laba kotor perusahaan.

\section{KAJIAN TEORI}

Modal kerja yaitu jumlah dari aktiva lancar. Jumlah ini merupakan modal kerja bruto (gross working capital). Definisi ini bersifat kuantitatif karena menunjukkan jumlah dana yang digunakan untuk maksud-maksud operasi jangka pendek. Waktu tersedianya modal kerja akan tergantung pada macam dan tingkat likuiditas dari unsur-unsur aktiva lancar misalnya kas, surat-surat berharga, piutang, dan persediaan (Jumingan 2011:66). Modal kerja dalam neraca mencakup aktiva lancar dan kewajiban lancar dalam jangka pendek, oleh sebab itu modal kerja bersih menggambarkan selisih antara aktiva lancar dan kewajiban lancar dalam perusahaan. Modal kerja menunjukkan besarnya investasi yang dilakukan perusahaan dalam aktiva lancar dan klaim atas perusahaan oleh adanya utang lancar (Arief Sugiono:2009), uraian diatas adalah konsep modal kerja kuantitatif dan kualitatif. Menurut Munawir (2010:14) terdapat tiga konsep modal kerja yaitu: konsep kuantitatif menitikberatkan untuk mencukupi kebutuhan perusahaan dalam membiayai operasinya yang bersifat rutin atau menunjukkan jumlah dana yang tersedia untuk tujuan operasi jangka 
pendek(gross working capital); konsep kualitatif menitikberatkan pada kualitas modal kerja, adalah kelebihan aktiva lancar terhadap hutang jangka pendek (net working capital), yaitu aktiva lancar yang berasal dari pinjaman jangka panjang maupun para pemilik perusahaan; konsep fungsional menitikberatkan fungsi dari dana yang dimiliki dalam rangka menghasilkan pendapatan (laba) dari usaha pokok perusahaan. Modal kerja merupakan salah satu unsur aktiva yang sangat penting dalam perusahaan karena tanpa modal kerja perusahaan tidak dapat memenuhi kebutuhan dana untuk menjalankan aktivitasnya (Drs.Sutrisno 2012:39). Menurut Agnes Sawir (2005:132) modal kerja terdiri modal kerja permanen dan modal kerja variabel. Modal kerja permanen adalah modal kerja yang harus tetap ada pada perusahaan untuk dapat menjalankan fungsi perusahaan secara terus-menerus diperlukan untuk kelancaran usaha; modal kerja variabel adalah modal kerja yang jumlahnya berubah-ubah sesuai dengan perubahan keadaan. Tujuan manajemen modal kerja adalah untuk memenuhi kebutuhan profitabilitas perusahaan, dengan modal kerja yang cukup perusahaan memiliki kemampuan untuk memenuhi kewajiban pada waktunya, memungkinkan untuk memperoleh tambahan dana daripada kreditor bila rasio keuangan memenuhi syarat, serta memaksimalkan penggunaan aktiva lancar guna meningkatkan penjualan (Kasmir 2012:253). Penelitian terdahulu: Pertama, Working capital level influence on SME profitability by Godfred Adjapong Afrifa; The Business School, Canterbury Christ Church University, Canterbury, UK, and Kesseven Padachi; Department of Economics and Finance, University of Technology, Port Louis, Mauritius "The empirical results show that there is a concave relationship between working capital level and firm profitability and that there is an optimal working capital level at which firms' profitability is maximized. Furthermore, an examination as to whether or not deviations from the optimal working capital level reduce firm profitability indicate the deviations above or below the optimum decrease profitability". Kedua, Working capital management and firms' profitability: evidence from emerging Asian countries by Monica Singhania; Faculty of Management Studies (FMS), University of Delhi, New Delhi, India, and Piyush Mehta, Netaji Subhas Institute of Technology (NSIT), University of Delhi, New Delhi, India. Finding - The study reveals a non linear relationship between profitability of a firm and WCM for 11 economies of the Asia pacific region. And also indicate that there exist relationships between working capital and profitability that resumble $\ddot{U}$ ". Ketiga, The status of working capital and its relationship with sales (An empirical investigation of Andhra Pradesh Paper Mills Ltd (India):36), the major findings of the research showed that while there was an increase in sales positively, strongly, and significantly associated with an increase in gross working capital for both the company and the industry.

Manajemen modal kerja sangat penting karena akan mempengaruhi laba perusahaan. Menurut para ahli: M. Nafarin (2007:788), laba adalah perbedaan antara pendapatan dengan keseimbangan biaya-biaya dengan pengeluaran untuk periode tertentu. Menurut Abdul Halim dan Bambang Supomo (2005:139), laba adalah pusat pertanggung jawaban yang masukan dan keluarnya diukur dengan menghitung selisih antara pendapatan dan biaya. Sedangkan menurut Mahmud M. Hanafi (2010:32), laba merupakan ukuran keseluruhan prestasi perusahaan, yang didefinisikan: Laba = Penjualan - Biaya. Laba memiliki peranan yang penting bagi perusahaan yaitu: Suatu kekuatan pokok agar perusahaan dapat tetap bertahan untuk jangka pendek dan jangka panjang; balas jasa atas dana yang ditanam perusahaan; salah satu sumber dana perusahaan; sumber dana jaminan surat karyawan; daya tarik bagi pihak ketiga yang ingin menanam dana (M. Nafarin 2007:231). Faktor-faktor yang mempengaruhi laba diantaranya: Biaya dari perolehan atau mengolah suatu produk atau jasa 
akan mempengaruhi harga jual produk yang bersangkutan; harga jual produk atau jasa akan mempengaruhi besarnya volume penjualan produk atau jasa yang bersangkutan; volume penjualan dan produksi berpengaruh pada volume produksi produk/jasa tersebut, selanjutnya volume produksi akan mempengaruhi besar kecilnya biaya produksi (Mulyadi 2001:513). Menurut Febrianto dan Widiastuty (2006) pengertian laba dapat dilihat dari tataran semantik masing-masing laba sebagai berikut: Laba kotor adalah selisih dari pendapatan perusahaan dikurangi dengan biaya barang terjual. Biaya barang terjual adalah semua biaya yang dikorbankan, untuk perusahaan pemanufakturan, mulai dari ketika bahan baku masuk pabrik, diolah dan hingga dijual; yang masuk ke rekening biaya barang terjual adalah biaya bahan baku, biaya tenaga kerja langsung, dan biaya-biaya overhead; angka laba kotor menggambarkan efisiensi manajer dalam menggunakan sumber daya perusahaan untuk menghasilkan produk. Angka laba operasi adalah selisih dari laba kotor dengan biaya-biaya operasi. Biaya operasi adalah biaya yang berhubungan dengan operasi perusahaan; perdefinisi biaya-biaya ini adalah yang sering terjadi di dalam perusahaan dan operatif sifatnya; selain itu biaya-biaya diasumsikan memiliki hubungan dengan penciptaan pendapatan. Angka laba bersih adalah angka yang menunjukkan selisih antara seluruh pendapatan yang operatif maupun tidak dan seluruh biaya yang operatif maupun tidak. Kasmir (2011) menyatakan bahwa: Laba kotor (Gross Profit) artinya laba yang diperoleh sebelum dikurangi biaya-biaya yang menjadi beban perusahaan; artinya laba keseluruhan yang pertama sekali perusahaan peroleh. Laba bersih (Net Profit) merupakan laba yang telah dikurangi biaya-biaya yang merupakan beban perusahaan dalam suatu periode tertentu termasuk pajak

Kiesno (2002:354) menjelaskan laba ditahan merupakan laba yang ditahan untuk digunakan dalam aktivitas bisnis. Sumber dasar laba ditahan adalah laba dari operasi. Pemegang saham menanggung risiko terbesar dalam operasi perusahaan dan memikul setiap kerugian dan keuntungan dari aktivitas perusahaan. Setiap laba yang tidak dibagikan kepada para pemegang saham akan menjadi tambahan ekuitas. Ridwan S. Sundjaja dan Inge Barliaan dalam buku "Manajemen Keuangan 2" (2004:380) mengatakan, laba ditahan merupakan pendapatan yang tidak dibagikan sebagai dividen, karenanya merupakan bentuk pembayaran interen. Sementara menurut penelitian terdahulu terkait dengan retained earning sebagai berikut: Pertama The Implications of Retained and Distributed Earnings for Future Profitability and Stock Returns. (RAF 9,4 page396) Retained earnings are related with the return of changes on net investment, while distributed earnings are cash flows related with external financing activities. Using these decompositions, we can examine possible realtions among the implications of different components of earnings for future profitability and stock returns and get a deeper understanding of their underlying causes. Ourfindings suggest that that there are potentially systematic differences in the persistence among the distinct components of retained earning and between the distinct components of distributed earnings. Accruals have lower persistence and investors overweight them, consistent with previous findings. Event though retained cash flows have higher persistence than accruals, investors overestimate it as well. In particular, investors act as if the components of retained earnings have simiar implications for future profitability, leading to an overvaluation of their differential persistence. Kedua Menurut Gusti Novrilia Sari (2013) meneliti tentang "Pengaruh Rasio Utang, Laba Ditahan, Return On Equity (ROE), dan Inflasi Terhadap Earnings Per Share (EPS) Perusahaan Makanan dan Minuman yang Terdaftar di Bursa Efek Indonesia (BEI) periode tahun 2008 - 2010". Hasil hipotesis menyatakan bahwa laba ditahan 
Hadi dan Wijaya: Modal Kerja Dan Laba Ditahan Merupakan...

\begin{tabular}{|l|l|l|l|l|l|l|l|l|}
\hline Tahun & 2010 & 2011 & 2012 & 2013 & 2014 & 2015 & 2016 & 2017 \\
\hline Sales & 612,192 & 813,342 & $1,190,826$ & $1,505,520$ & $1,880,263$ & $2,174,502$ & $2,521,921$ & $2,491,100$ \\
\hline COGS & 323,167 & 433,938 & 634,413 & 806,918 & 978,841 & $1,019,511$ & $1,220,833$ & $1,183,169$ \\
\hline Gross Profit & 289,025 & 379,404 & 556,413 & 698,602 & 901,421 & $1,154,990$ & $1,301,088$ & $1,307,931$ \\
\hline Beban Usaha & 153,367 & 226,177 & 357,010 & 466,211 & 602,698 & 701,332 & 858,043 & $1,050,766$ \\
\hline EBIT & 135,658 & 153,227 & 199,403 & 232,391 & 298,723 & 453,658 & 443,045 & 257,165 \\
\hline EBT & 134,666 & 154,948 & 199,793 & 210,805 & 252,857 & 378,252 & 369,417 & 186,147 \\
\hline EAT & 99,775 & 115,933 & 149,150 & 158,015 & 192,412 & 263,711 & 263,392 & 124,468 \\
\hline EPS(Rupiah) & 106.38 & 114.52 & 29.47 & 31.22 & 37.27 & 53.45 & 55.31 & 27.66 \\
\hline
\end{tabular}

berpengaruh positif terhadap Earnings Per Share (EPS) perusahaan makanan dan minuman yang terdaftar di Bursa Efek Indonesia periode tahun 2008 - 2010.

Dalam penelitian ini, yang menjadi subjek penelitian adalah PT. Nippon Indosari Corpindo Tbk. merupakan perusahaan yang bergerak dibidang makanan dan minuman, mulai beroperasi sejak tahun 1995 dan go public pada tanggal 23 Juni 2010 dengan kode saham ROTI. Pabrik- pabrik tersebar di Jawa Bara, Cikarang Barat (sebagai Kantor Pusat), Cikarang Utara, Cibitung, Purwakarta, Cikande (Banten), di Semarang (Jawa Tengah), Pasuruan (Jawa Timur), Medan (Sumatera Utara), Palembang (Sumatera Selatan) dan Makasar (Sulawesi Selatan). Pada tahun 2015 sampai dengan sekarang, perseroan menerapkan standar ISO 9001:2008(Quality Management System) dan ISO 22000:2005(Food Safety Management system).

Untuk memberi gambaran yang lebih jelas maka penulis melampirkan tabel perusahaan dari bagian laporan keuangan: neraca, laba rugi, dan perubahan modal sebagai berikut:

Tabel 4.1

Bagian Laporan Neraca 2010-2017 (dalam jutaan rupiah)

\begin{tabular}{|l|c|c|c|c|c|c|c|c|}
\hline \multicolumn{1}{|c|}{ Tahun } & $\mathbf{2 0 1 0}$ & $\mathbf{2 0 1 1}$ & $\mathbf{2 0 1 2}$ & $\mathbf{2 0 1 3}$ & $\mathbf{2 0 1 4}$ & $\mathbf{2 0 1 5}$ & $\mathbf{2 0 1 6}$ & $\mathbf{2 0 1 7}$ \\
\hline Aset lancar & 213,030 & 190,274 & 219,818 & 363,881 & 420,316 & 812,991 & 949,414 & $2,319,937$ \\
\hline Aset tidak lancar & 355,235 & 568,863 & 985,127 & $1,458,808$ & $1,722,578$ & $1,893,333$ & $1,970,227$ & $2,239,636$ \\
\hline Total aset & 568,265 & 759,137 & $1,204,945$ & $1,822,689$ & $2,142,894$ & $2,706,324$ & $2,919,641$ & $4,559,574$ \\
\hline Liabilitas lancar & 92,639 & 148,209 & 195,456 & 320,197 & 307,609 & 395,920 & 320,502 & $1,027,177$ \\
\hline Liabilitas tdk lancar & 20,174 & 64,487 & 342,882 & 725,528 & 881,703 & $1,121,869$ & $1,156,387$ & 712,291 \\
\hline Total liabilitas & 112,813 & 212,696 & 538,337 & $1,045,725$ & $1,189,311$ & $1,517,789$ & $1,476,889$ & $1,739,468$ \\
\hline Total ekuitas & 455,452 & 546,441 & 666,608 & 776,964 & 953,583 & $1,188,535$ & $1,442,752$ & $2,820,106$ \\
\hline Liabilitas\& Ekuitas & 568,265 & 759,137 & $1,204,945$ & $1,822,689$ & $2,142,894$ & $2,706,324$ & $2,919,641$ & $4,559,574$ \\
\hline
\end{tabular}

Tabel 4.2

Bagian Laporan Laba Rugi 2010-2017 (dalam jutaan rupiah)

Sumber:<PT.Nippon Indosari Corpindo Annual Report, 2010-2017

Tabel 4.2

Bagian Laporan Perubahan Modal 2010-2017 (dalam jutaan rupiah)

\begin{tabular}{|l|l|l|l|l|l|l|l|l|}
\hline \multicolumn{1}{|c|}{ Tahun } & \multicolumn{1}{|c|}{$\mathbf{2 0 1 0}$} & $\mathbf{2 0 1 1}$ & $\mathbf{2 0 1 2}$ & $\mathbf{2 0 1 3}$ & $\mathbf{2 0 1 4}$ & $\mathbf{2 0 1 5}$ & $\mathbf{2 0 1 6}$ & $\mathbf{2 0 1 7}$ \\
\hline Ak. Laba ditahan & 181,215 & 272,204 & 392,370 & 502,726 & 679,346 & 915,065 & $1,127,742$ & $1,193,185$ \\
\hline Ak. Perubahan modal & 455,452 & 546,441 & 666,608 & 776,964 & 953,583 & $1,188,535$ & $1,442,752$ & $2,820,106$ \\
\end{tabular}

Berdasarkan tiga tabel tersebut diatas dari akhir Desember 2010 sampai pada akhir Desember 2017 neraca menunjukkan trend yang positif dari tahun ke tahun yaitu total asset, total liabilitas, dan total ekuitas.

Laporan laba rugi (volume penjualan, gross profit, dan EAT) pertumbuhan dari tahun ke tahun pada umumnya menunjukkan trend yang positif kecuali pada tahun 2017 EAT agak menurun, dikarenakan adanya kenaikan beban usaha. Untuk EPS pada tahun 2012 kelihatannya menurun dibandingkan dengan tahun 2011, hal ini disebabkan adanya 
kebijakan perusahaan 2012 menurunkan nilai nominal saham dari Rp1.000 per lembar menjadi Rp100 perlembar saham (turun 90\% dari nilai nominal 2011). Jumlah saham beredar menambah 900\% dari jumlah saham tahun 2011 dan tahun 2017 ada penerbitan saham baru.

Laporan perubahan modal menunjukkan trend yang postif dari tahun ke tahun, artinya setiap tahun ada penambahan laba ditahan. Berdasarkan deskriptif subyek penelitian dapat disimpulkan bahwa PT. Nippon Indosari Corpindo Tbk. bergerak dibidang makkanan dan minuman sudah Go Public memiliki total asset, total liabilitas, dan total ekuitas dari akhir tahun 2010 sampai dengan akhir tahun 2017 menunjukkan trend yang positif pada umumnya, begitu juga EAT dan EPS.

\section{METODOLOGI}

Dalam penelitian ini penulis menetapkan subyek riset adalah perusahaan PT. Nippon Indosari Corpindo Tbk. Obyek riset menggunakan data sekunder berupa laporan keuangan perusahaan audited akuntan publik dan dipublikasikan untuk umum, pengumpulan data dilakukan dengan masuk internet www.sariroti.com/informasi-investor/\#laporan-keuangan untuk mendapatkan semua data yang diperlukan dalam penelitian ini.

Jenis penelitian adalah deskriptif dengan menggunakan data laporan keuangan dan pendekatan kuantitatif. Data dikumpulkan dan diolah kedalam bentuk tabel sesuai kebutuhan untuk mempermudah analisis data.

Penelitian ini bertujuan mengetahui variabel-variabel keuangan perusahaan yang terkait dengan variabel dependen, yaitu laba kotor perusahaan; variabel independen modal kerja dan laba ditahan sebagai prediktor yang positif terhadap variabel dependen laba kotor perusahaan.

Dalam menganalisis data menggunakan alat analisis Software SPSS IBM Versi 24 dengan variabel dependen (Y) adalah laba kotor perusahaan yang akan diprediksi oleh variabel independen yakni modal kerja (X1) dan laba ditahan (X2).

Sebelum melakukan uji kebenaran empiris hipotesis, penulis terlebih dahulu melakukan uji asumsi, yaitu: Uji multikolinearitas, untuk menguji apakah pada model regresi ditemukan adanya korelasi antar variabel indenpenden. Uji otokorelasi, untuk menguji apakah dalam model regresi terdapat korelasi antara kesalahan pengganggu pada periode $\mathrm{t}$ dengan kesalahan pengganggu pada periode t-1. Uji normalitas, untuk menguji apakah dalam suatu model regresi memiliki nilai residual yang berdistribusi normal atau tidak. Uji heteroskedastisitas, untuk menguji apakah dalam model regresi terjadi ketidaksamaan variansi dari residu suatu pengamatan dengan pengamatan lainnya.

Uji F dan uji T menurut Keni dan Raldy Benedict, Modul Praktikum Statistik II (2017:70-74) Untuk memutuskan apakah persamaan regresi yang diperoleh dapat atau tidak dapat digunakan untuk memprediksi, maka kita harus melakukan uji $\mathrm{F}$ serta uji t-test terhadap tiap koefisien regresi dan intersepnya. Uji $\mathrm{F}$ dilakukan lebih dulu, yakni untuk mengetahui apakah secara bersama - sama kedua koefisien regresi yang diperoleh signifikan untuk digunakan, sedangkan uji t-test dilakukan untuk menguji signifikansi koefisien regresi secara sendiri - sendiri dan intersepnya. Khusus untuk koefisien regresi, jika hasil uji $F$ signifikan maka paling sedikit ada satu koefisien regresinya signifikan. Sebaliknya, jika hasil uji F tidak signifikan maka tidak ada satupun koefisien regresinya yang signifikan.

Sebelum melakukan pengumpulan dan pengolahan data, penulis terlebih dahulu menuliskan nama dari 18 perusahaan makanan dan minuman yang terdaftar BEI. Lalu 
penulis undi dengan mengocok dari 18 perusahaan dan akhirnya mendapatkan satu perusahaan, yaitu PT. Nippon Indosari Corpindo Tbk.

Hasil Analisis Data. Hasil uji asumsi analisis data dari data sekunder times series pada perusahaan makanan dan minuman PT. Nippon Indosari Corpindo Tbk. dengan variabel independen modal kerja dan laba ditahan, serta variabel dependen laba kotor.

Dari hasil uji keempat asumsi tersebut diatas, lolos semua dari persyaratannya, maka penulis melanjutkan uji fisher $(\mathrm{F})$ dan uji t-test:

Uji signifikansi koefisien regresi ganda menggunakan uji $\mathrm{F}$ dengan rumusan hipotesis:

Ho : $\beta 1=\beta 2=0$ (tidak ada hubungan yang signifikan variabel modal kerja dan variabel laba ditahan dengan variabel laba kotor perusahaan)

Ha : $\beta 1 \neq \beta 2 \neq 0$ (paling sedikit ada satu variabel modal kerja atau variabel laba ditahan mempunyai hubungan dengan variabel laba kotor perusahaan)

Dengan tingkat keyakinan 95\%

\begin{tabular}{|c|c|c|c|c|}
\hline \multicolumn{5}{|c|}{ Model Summary } \\
\hline Model & $\mathrm{R}$ & R Square & Adjusted R Square & Std. Error of the Estimate \\
\hline 1 & $.997^{a}$ & .994 & .991 & 38459330970.000 \\
\hline
\end{tabular}

\begin{tabular}{|c|c|c|c|c|c|c|}
\hline \multicolumn{7}{|c|}{ ANOVA $^{a}$} \\
\hline Model & & Sum of Squares & df & Mean Square & $\mathrm{F}$ & Sig. \\
\hline \multirow[t]{3}{*}{1} & Regression & 1141145735000000000000000.000 & 2 & 570572867500000000000000.000 & 385.752 & $.000^{\mathrm{b}}$ \\
\hline & Residual & 7395600693000000000000.000 & 5 & 1479120139000000000000.000 & & \\
\hline & Total & 1148541336000000000000000.000 & 7 & & & \\
\hline
\end{tabular}

Dari hasil analisis data pada tabel ANOVA dengan variabel dependen laba kotor menunjukkan tingkat signifikan lebih kecil dari nilai probabilitas artinya hipotesis nol (Ho) ditolak dan hipotesis alternatif (Ha) diterima, maka dapat dikatakan paling sedikit ada satu variabel modal kerja atau laba ditahan mempunyai hubungan dengan variabel laba kotor perusahaan secara bersama - sama dengan tingkat keyakinan $95 \%$.

Koefisien Determinasi Ganda (R Square), tabel Model Summary nilai R Square sebesar $0,99 \times 100 \%=99 \%$. Jadi sebesar $99 \%$ variansi variabel laba kotor dapat dijelaskan variabel modal kerja dan laba ditahan. Sedangkan sisanya sebesar 1\% dijelaskan variabel lainnya.

Uji t-test dengan rumusan hipotesis:

Ho : $\beta 1=0$ (tidak ada hubungan yang signifikan modal kerja dengan laba kotor)

Ha : $\beta 1 \neq 0$ (ada hubungan yang signifikan modal kerja dengan laba kotor)

Dengan tingkat keyakinan $95 \%$

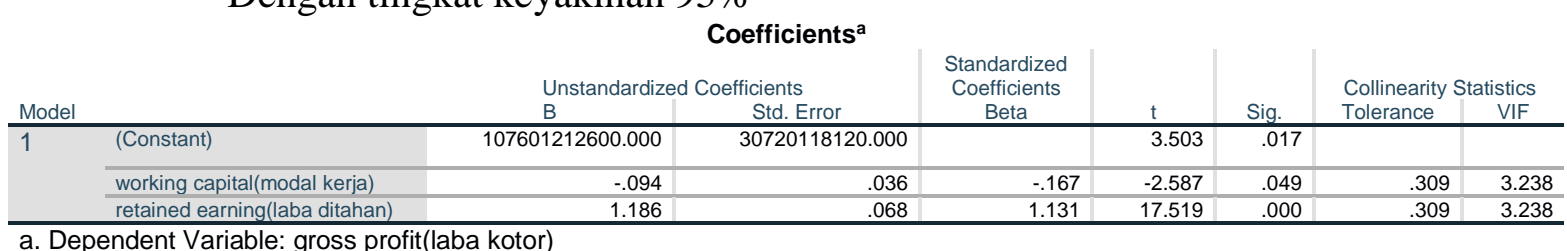

a. Dependent Variable: gross profit(laba kotor) 
Dari hasil analisis data pada tabel coefiicent hubungan variabel modal kerja dengan laba kotor perusahaan dengan signifikansi lebih kecil dari nilai probabilitas; artinya hipotesis nol (Ho) ditolak dan hipotesis alternatif (Ha) diterima. Artinya ada hubungan yang signifikan antara variabel modal kerja dengan variabel laba kotor perusahaan dengan tingkat keyakinan 95\%;kolom unstandardized coefficients (B) modal kerja mempunyai hubungan dengan laba kotor lebih kecil dari nol, maka hubungan modal kerja dengan laba kotor adalah negatif.

Ho : $\beta 2=0$ (tidak ada hubungan yang signifikan variabel laba tahan dengan variabel laba kotor)

Ha : $\beta 2 \neq 0$ (ada hubungan yang signifikan variabel laba ditahan dengan variabel laba kotor) Dengan tingkat keyakinan $95 \%$

Dari hasil analisis data pada tabel coefficients hubungan variabel laba ditahan dengan laba kotor dengan signifikansi lebih kecil dari nilai probabilitas artinya hipotesis nol (Ho) ditolak, dengan demikian hipotesis alternatif (Ha) diterima. Artinya ada hubungan yang signifikan antara variabel laba ditahan dengan variabel laba kotor perusahaan dengan tingkat keyakinan 95\% dan pada kolom unstandardized coefficient (B), variabel laba ditahan mempunyai hubungan dengan laba kotor lebih besar dari nol, maka hubungan laba ditahan dengan laba kotor adalah positif.

\section{DISKUSI}

Hasil statistik analisis data penelitian bahwa modal kerja dan laba ditahan secara bersama-sama sebagai prediktor yang positif terhadap laba kotor dengan nilai $\mathrm{F}$ observasi positif dan signifikannya kuat. Ini menunjukkan korelasi yang kuat antara laba kotor dengan modal kerja dan laba ditahan secara bersama - sama, sehingga dapat dikatakan bahwa modal kerja dan laba ditahan sebagai prediktor yang positif terhadap laba kotor perusahaan. Hal ini sesuai dengan harapan penelitian ini dan penelitian terdahulu juga sama bahwa modal kerja dalam batas tertentu secara simultan berpengaruh secara positif terhadap profitabilitas.

Uji secara parsial menurut teori bahwa modal kerja mempunyai hubungan yang positif dengan profit selama dalam batas- batas tertentu.

Menurut Munawir modal kerja yang cukup menguntungkan perusahaan untuk beroperasi secara ekonomis atau efisien dan tidak mengalami kesulitan keuangan (2014:116). Menurut Drs. Sutrisno modal kerja sangat penting memenuhi kebutuhan dana untuk menjalankan aktivitasnya (2012:39), modal kerja berfungsi membiayai operasi perusahaan untuk memperoleh profit, sehingga berpengaruh positif terhadap profitabilitas.

Hasil penelitian sebelumnya juga menunjukkan hubungan positif antara modal kerja kotor dengan profit dalam batas tertentu. Hasil penelitian ini menghasilkan nilai uji t bahwa hubungan modal kerja dengan laba kotor negatif dan signifikansi yang lemah, hal ini mungkin disebabkan kenaikan modal kerja yang sangat tinggi pada tahun 2017, karena perusahaan menerbitkan saham baru HMETD (hak memesan efek terlebih dahulu) pada tahun 2017 yang mengakibatkan terjadinya penambahan modal kedalam kas perusahaan.

Pada tabel coefficients, hubungan laba ditahan dengan laba kotor ada hubungan yang signifikan. Berdasarkan definisi laba ditahan menurut Ridwan S. Sanjaya dan Inge Barliaan, laba ditahan merupakan pendapatan yang tidak dibagikan sebagai deviden, karenanya merupakan bentuk pembiayaan interen (2004:380). Menurut Zaki Baridwan Saldo laba tidak 
dibagikan (laba ditahan) dimaksudkan agar tidak mengganggu jalannya usaha perusahaan (2001:267). Sehingga dapat disimpulkan bahwa laba ditahan sebagai sumber pembiayaan yang murah untuk pembiayaan operasi perusahaan dan reinvestasi untuk meningkatkan profit perusahaan atau laba ditahan berpengaruh positif terhadap profitabilitas.

Dari hasil penelitian sebelumnya juga menunjukkan modal kerja mempunyai hubungan yang positif dengan laba, yaitu jurnal yang terdapat di kajian teori. Pertama Effect of working capital management on SME profitability. Menurut hasil penelitian ini bahwa modal kerja merupakan suatu faktor penting dan berdasarkan bukti impiris modal kerja mempengaruhi laba di perusahaan kecil dan menengah. Penulis ini juga menyatakan bahwa berdasarkan analisis terdahulu yang fokus pada perusahaan besar juga berlaku hal yang sama. Kedua Working capital management and firms' profitability: evidence from emerging Asian countries. Penelitian ini menunjukkan hubungan yang tidak linear antara laba perusahaan dan manajemen modal kerja untuk sebelas sektor ekonomi di Asia Pasifik. Ketiga Working capital financing and corporate profitability of Indian manufacturing firms. Menurut hasil penelitian ini terdapat hubungan cembung (positif) antara modal kerja dan laba perusahaan di industri makanan dan minuman, kimia dan konstruksi. Keempat Working capital level influence on SME profitability. Hasil empiris menunjukkan bahwa ada hubungan cekung antara tingkat modal kerja dan laba perusahaan pada tingkat modal kerja optimal akan menghasilkan laba yang maksimal, penambahan atau pengurangan modal kerja akan mengurangi laba perusahaan. Kelima The status of working capital and its relationship with sales. Hasil penelitian ini menunjukkan ketika penjualan naik secara positif, kuat dan signifikan berkaitan dengan kenaikan modal kerja baik di dunia usaha maupun industry. Keenam teori dari Riyanto (2001) Kemampuan suatu perusahaan dengan seluruh modal yang bekerja di dalamnya untuk menghasilkan laba. Laba yang besar saja belumlah merupakan ukuran bahwa perusahaan itu telah dapat bekerja dengan efisien. Efisiensi baru dapat diketahui dengan membandingkan laba yang diperoleh ini dengan kekayaan atau modal yang menghasilkan laba tersebut. Jadi dapat disimpulkan bahwa baik berdasarkan teoritis maupun bukti impiris bahwa modal kerja mempengaruhi laba perusahaan baik perusahaan kecil, menengah maupun perusahaan besar dan hubungannya bersifat non linear, cembung dan cekung antara tingkatan modal kerja dengan laba perusahaan dimana terdapat tingkat modal kerja optimal yang dapat menghasilkan laba maksimal, artinya penambahan atau pengurangan modal kerja yang berlebihan dapat mengurangi laba perusahaan (the law of diminishing return).

Hasil analisis statistik hipotesis uji t bahwa hubungan antara laba ditahan dengan laba kotor adalah positif dan signifikansi kuat. Ini menunjukkan korelasi yang kuat antara laba kotor perusahaan dengan laba ditahan. Sehingga dapat dikatakan bahwa laba ditahan sebagai prediktor yang positif terhadap laba kotor perusahaan sesuai dengan hipotesis penelitian ini.

Hasil penelitian sebelumnya juga menunjukkan bahwa laba ditahan mempunyai hubungan yang positif dengan profit, antara lain dari Jurnal: The implications of retained and distributed earnings for future profitability and stock returns. Hasil penelitian ini menunjukkan adanya perbedaan tingkat keyakinan antara laba ditahan dan laba dibagikan untuk laba perusahaan dan tingkat keuntungan yang didapat para pemegang saham di masa depan, dimana tingkat keyakinan lebih tinggi untuk laba ditahan daripada laba dibagikan. Kedua "Pengaruh Rasio Utang, Laba Ditahan, Return On Equity (ROE), dan Inflasi Terhadap Earnings Per Share (EPS) Perusahaan Makanan dan Minuman yang Terdaftar di Bursa Efek Indonesia (BEI) periode tahun 2008 - 2010". Hasil hipotesis menyatakan bahwa laba ditahan berpengaruh positif terhadap Earnings Per Share (EPS). Jadi dapat disimpulkan 
bahwa baik berdasarkan teoritis maupun bukti impiris bahwa laba ditahan berpengaruh positif terhadap laba perusahaan.

\section{KESIMPULAN}

Untuk PT. Nippon Indosari Corpindo Tbk. dari hasil penelitian dan teoritis serta penelitian terdahulu bahwa modal kerja memiliki hubungan yang positif dalam batas-batas tertentu untuk menghasilkan laba yang optimal sehingga dalam penentuan modal kerja, manajemen harus memperhatikan batas modal kerja yang optimal sehingga bisa menghasilkan laba yang optimal juga. Sedangkan untuk laba ditahan juga menghasilkan hubungan yang positif dengan laba perusahaan karena laba ditahan merupakan sumber pendanaan internal untuk membiayai berbagai aktivitas operasional perusahaan serta reinvestasi untuk pengembangan usaha dalam rangka meningkatkan laba perusahaan (nilai tambah perusahaan). Untuk penelitian selanjutnya, agar menambah data subjek penelitian (N) dan periode data (n)sehingga dapat menghasilkan penelitian yang lebih akurat.

\section{DAFTAR PUSTAKA}

Afrifa, Godfred Adjapong \& Kesseven Padachi. (2016). Working capital level influence on SME profitability. Journal of Small Business and Enterprise Development, 23(1),44.

Benedict,Raldy\&Keni(2017). Modul Praktikum Statistik II. Jakarta: Universitas Tarumanagara

Jumingan (2011). Analisis Laporan Keuangan . Jakarta: Bumi Aksara

Nafarin, M (2007). Penganggaran Perusahaan. Jakarta: Salemba Empat

Papanastasopoulos, Georgios, Dimitrios Thomakos, \& Taowang. (2010). The implications of retained and distributed earnings for future profitability and stock return. Review of ccounting and Finance, 9(4), 396.

Panda, Aruna. (2012). The status of working capital and its relationship with sales. International Journal of Commerce and Management, 22(1),36.

POLSRI REPOSITORY (2015). BAB II TINJAUAN PUSTAKA (Retrieved from:(PDF)eprints. polsri.ac.id $>$....)

Panda, Ajaya Kumar. (2018). Working capital financing and corporate profitability of Indian manufacturing firms. Management Decision, 56(2), 443.

Riyanto, Bambang (2011). Dasar - Dasar Pembelanjaan Perusahaan. Yogyakarta: BPPE

Sawir, Agnes (2005). Analisis Kinerja Keuangan dan Perencanaan Keuangan. Jakarta: PT.Gramedia Pustaka Utama

Sugiono, Arief (2009). Manajemen Keuangan untuk Praktisi Keuangan. Jakarta: PT.Gramedia Widiasarana Indonesia

Sutrisno (2012). Manajemen Keuangan Teori, Konsep dan Aplikasi. Yogyakarta: EKONISIA

Sari, Gusti Novrilia (2013). Pengaruh Rasio Utang, Laba Ditahan, Return On Equity (ROE) dan Inflasi Terhadap Earnings Per Share (EPS) Perusahaan Makanan dan Minuman yang Terdaftar Di Bursa Efek Indonesia Periode Tahun 2008-2010. Skripsi. Universitas Negeri Yogyakarta. Yogyakarta.

Singhania, Monica \& Piyush Mehta. (2017). Working capital management and firms'profitability: evidence from emerging Asian countries. South Asian Journal of Business, 6(1),80-81. 
Wordpress. (2015) Modal Kerja: Pengertian, Konsep, Jenis, Manfaat, Penggunaan, Manajemen dan Perputaran (Retrieved from: https://datakata.wordpress.com/ 2015/10/18/modal-kerja-pengertian konsep-jenismanfaatpenggunaan-manajemendan-perputaran/) 